\title{
EVALUASI PNPM MANDIRI KELAUTAN DAN PERIKANAN DALAM MENDUKUNG INDUSTRIALIASI PERIKANAN
}

\section{Evaluation of Marine And Fisheries National Program on People Empowerement in Support to Fishery Industrialization}

\author{
Siti Hajar Suryawati ${ }^{1}$, Andrian Ramadhan ${ }^{1}$, Mira $^{1}$, Nensyana Safitri', \\ Subhechanis Saptanto ${ }^{1}$ dan Agus Heri Purnomo ${ }^{2}$ \\ ${ }^{1}$ Balai Besar Penelitian Sosial Ekonomi Kelautan dan Perikanan \\ JI. KS. Tubun Petamburan VI Jakarta 10260 \\ Telp. (021) 53650162, Fax. (021)53650159 \\ ${ }^{2}$ Peneliti Balai Besar Litbang Pengolahan Produk dan Bioteknologi Kelautan dan Perikanan \\ Email: siti_suryawati@yahoo.com
}

Diterima 13 September 2013 - Disetujui 29 Nopember 2013

\begin{abstract}
ABSTRAK
Perikanan merupakan salah satu sumber pendapatan nasional dan lapangan pekerjaan bagi masyarakat Indonesia. Peran penting sektor tersebut pada saat ini belum diiringi dengan pengoptimalan pemanfaatan potensi yang ada. Salah satu upaya pemerintah adalah melalui Program Nasional Pemberdayaan Masyarakat Mandiri Kelautan dan Perikanan (PNPM Mandiri KP) sebagai upaya untuk mengentaskan kemiskinan yang lebih dari 60 persen berada di wilayah pesisir. Anggaran yang tidak sedikit dikucurkan untuk program tersebut. Penelitian ini bertujuan untuk mengidentifikasi kinerja outcome dan kinerja manfaat dan dampak dari PNPM Mandiri KP pada berbagai usaha perikanan. Penelitian dilakukan pada bulan Januari - Mei 2013. Metode pengolahan data yang digunakan pada penelitian ini adalah metode deskriptif. Hasil penelitian menunjukkan bahwa kinerja outcome PNPM Mandiri KP pada kelompok perikanan tangkap, pembudidaya ikan, pengolah/pemasar, dan petambak garam berturut-turut adalah: 1) 19 persen, 37 persen, 27 persen dan 31 persen untuk peningkatan produksi dan produktivitas; dan 2) 54 persen, 33 persen, 57 persen dan 31 persen untuk peningkatan pendapatan. Kinerja manfaat dan dampak seperti tercantum dalam petunjuk pelaksanaan PNPM Mandiri KP yaitu perkembangan usaha, berfungsinya kelompok sebagai lembaga ekonomi dan berkurangnya kemiskinan di lokasi program belum terindikasi secara eksplisit karena terkendala sistem pendataan yang tidak mencakup pengukuran kinerja tersebut. Rekomendasi yang diusulkan sebagai perbaikan kebijakan di masa mendatang diantaranya adalah: 1) program harus diarahkan pada pembinaan dalam aspek kewirausahaan, manajemen usaha dan manajemen keuangan; 2) masyarakat yang tidak menerima bantuan dilibatkan sebagai bagian dari skenario program; dan 3) menyertakan programprogram pembinaan dan pendampingan yang diarahkan pada penyiapan penerima program untuk memanfaatkan kenaikan pendapatannya untuk digunakan sebagai fasilitas yang dapat meningkatkan produksi dan pendapatan lebih besar lagi pada saat mereka tidak lagi mendapatkan bantuan.
\end{abstract}

Kata Kunci: pemberdayaan masyarakat, Industrialisasi, PNPM, PUMP, PUGAR, PDPT

\section{ABSTRACT}

Fisheries represents a notable source of income generation and job creation for Indonesia. The important role of fisheries has so far not been followed by optimalization of the existing potentials. Recognizing this, the government is currently carried out a program called the Marine and Fisheries Mandiri National Program on People Empowerment (PNPM Mandiri KP), which represents a relevant effort to alleviate poverty, wherein $60 \%$ of which occurs in the coastal areas. A significant amount of budget has been allocated to this program. This objective of this research is to identify the benefit, impact and outcome performance of the program. The research was carried out during the period of January to May 2013. The data processing and interpretation approach that was adopted in this research is descriptive approach. The research shows that the outcome performance of the program in capture 
fishery, aquaculture and fish processor/marketer groups are respectively 19 percent, 37 percent, 27 percent and 31 percent for production and productivity increases and respectively 54 percent, 33 percent, 57 percent and 31 percent for the income increase. Benefit and income performances, which include business development, functioning groups as economic institutions and poverty reduction in the area has not been indicated explicitly due to lack of data. This paper suggests that future improvement can be advanced through the following: 1) putting more attention on development of entrepreneurship, business management and financial management; 2) involving non-receivers in the program scenario; and 3) including empowerment program to recipients to utilize their income tobe used as a facilityto increase production and more income when they didn't get program anymore.

Keywords: community empowerment, industrialization, PNPM, PUMP, PUGAR, PDPT

\section{PENDAHULUAN}

Kemiskinan telah menjadi isu dunia karena seperempat penduduk dunia dewasa ini, sebagaimana dilaporkan oleh The World Bank (2004), tergolong miskin. Untuk Indonesia, relevansi isu tersebut diindikasikan oleh data kemiskinan yang mencapai 34,96 juta jiwa, yang 63,47 persen di antaranya adalah masyarakat yang hidup di kawasan pesisir dan pedesaan (BPS, 2008). Untuk itu, pengentasan kemiskinan pada masyarakat pesisir menjadi salah satu kebijakan utama Kementerian Kelautan dan Perikanan. Salah satu strategi yang diterapkan oleh Kementerian Kelautan dan Perikanan dalam rangka melaksanakan kebijakan tersebut di atas adalah mengoptimalkan Program Nasional Pemberdayaan Masyarakat (PNPM) Mandiri Kelautan dan Perikanan, yang bentuk operasionalisasinya adalah Pengembangan Usaha Mina Pedesaan (PUMP), Pemberdayaan Usaha Garam Rakyat(PUGAR) dan Pengembangan Desa Pesisir Tangguh (PDPT).

PUMP merupakan program pemberdayaan bagi peningkatan kesejahteraan dan kesempatan kerja bagi masyarakat nelayan, pembudidaya serta pengolah dan pemasar hasil perikanan. Sementara itu, PUGAR adalah kegiatan pemberdayaan yang difokuskan pada peningkatan kesempatan kerja dan kesejahteraan bagi petambak garam dalam rangka mencapai Swasembada Garam Nasional. Adapun PDPT adalah kegiatan pembangunan wilayah desa pesisir berbasis pemberdayaan masyarakat untuk meningkatkan kesejahteraan masyarakat pesisir dan kesiapan terhadap bencana dan perubahan iklim. Program-program ini diharapkan sebagai motor pemberdayaan masyarakat dan pengentasan kemiskinan di masyarakat pesisir, melaluipeningkatan produksi, produktivitas, dan penyerapan tenaga kerja di masyarakat pesisir melalui program bantuan yang diberikan untuk modal kerja.

Salah satu upaya nyata yang dilakukan oleh KKP dalam rangka implementasi kebijakan dan strategi tersebut di atas adalah peningkatan alokasi BLM PNPM Mandiri KP pada Tahun 2012, yang mencapai 89,33 persen (Rp 782,94 miliar) (KKP, 2012). Peningkatan tersebut dilakukan untuk memperluas jangkauan sasaran penerima. Pada tahun sebelumnya, alokasinya sebesar Rp 404 miliar. Alokasi tersebut untuk program PUMP budidaya saja pada tahun 2011 melampaui target yang ditentukan yaitu 101,89 persen atau 6,97 juta ton. Padahal target produksi yang diharapkan dari peningkatan produksi program PUMP hanya 6,84 ton, untuk disalurkan ke 33 propinsi dan 300 Kabupaten dengan 2 ribu kelompok penerima. Bantuan tersebut dirancang untuk tidak hanya dalam bentuk dana untuk usaha melainkanjuga dalam bentuk pembinaan dan pendampingan, misalnya pembinaan pemahaman terhadap Cara Budidaya Ikan yang Baik (CBIB) atau Good Aquaculture Practices (GAP). Hal ini dilakukan guna menjamin keberlanjutan usaha perikanan serta memenuhi jaminan mutu dan keamanan hasil perikanan sebagaimana yang dipersyaratkan oleh pasar global.

Penggunaan anggaran yang cukup besar perlu dievaluasi dan dimonitor, dengan maksud untuk melihat seberapa besar dampak manfaat yang diciptakan dari implementasi kebijakan, strategi dan upaya tersebut di atas. Dengan demikian akan dapat diketahui faktor apa saja yang menjadi keunggulan dan kelemahannya, sekaligus dapat dijadikan sebagai bahan infomasi yang sangat penting untuk perbaikan program secara lebih akurat, efektif dan efisien. Kajian ini bertujuan untuk menganalisis dampak program dan 
kegiatan pembangunan kelautan dan perikanan terpilih selama tahun 2011 - 2012 yang meliputi kegiatan analisis dan sintesis terhadap konsep/ rancangan, implementasi dan dampak program, serta implikasinya bagi penyusunan kebijakan di masa mendatang.

\section{METODOLOGI}

Penelitian dilakukan dengan dengan menggunakan pendekatan desk study, mencakup analisis dan sintesis terhadap konsep/rancangan, implementasi dan dampak program PNPM Mandiri $\mathrm{KP}$, serta implikasinya bagi penyusunan kebijakan di masa mendatang. Jenis data yang digunakan pada penelitian ini meliputi data sekunder dan data primer. Data sekunder diperoleh dari dokumentasi dan publikasi hasil pengkajian dan pendataan yang telah dilakukan. Data primer merupakan data yang akan dikumpulkan langsung kepada masyarakat dan stakeholder lainnya yang terkait.

\section{PNPM MANDIRI KELAUTAN DAN PERIKANAN}

\section{Pengembangan Usaha Mina Pedesaan Perikanan Tangkap (PUMP-PT)}

Kegiatan pokok PUMP-PT pada tahun 2012 diantaranya adalah: 1) Identifikasi, seleksi dan verifikasi KUB calon penerima BLM PUMP PT; 2) Pengusulan dan penetapan KUB calon penerima penerima BLM PUMP-PT; 3) Penyusunan dan verifikasi dokumen administrasi; 4) Proses penyaluran dan pencairan dana BLM PUMP-PT; 5) Pendampingan, pembinaan dan pengendalian; dan 6) Pemantauan, evaluasi dan pelaporan.

Penentuan alokasi BLM per Kabupaten/Kota ditentukan oleh Pokja Perikanan Tangkap dengan mempertimbangkan hal-hal berikut ini: 1) Jumlah KUB binaan Kabupaten/Kota; 2) Jumlah Alokasi BLM di Kabupaten/Kota yang telah direalisasikan sebelumnya; 3) Jumlah anggota KUB yang belum mendapatkan BLM; 4) Kemampuan pembinaan dan pengendalian dari Kabupaten/Kota; 5) Alokasi dana pendukung untuk pembinaan yang disediakan oleh Kabupaten/Kota; dan 6) Evaluasi kegiatan PUMP tahun sebelumnya.

\section{Pengembangan Usaha Mina Pedesaan Perikanan Budidaya (PUMP-PB)}

Tujuan dilaksanakannya PUMP-PB adalah: 1) Meningkatkan produksi perikanan budidaya;

2) Meningkatkan pendapatan dan kesejahteraan masyarakat untuk mengurangi kemiskinan; 3) Menumbuhkan wirausaha di bidang perikanan budidaya; 4) Memperluas dan menyediakan lapangan kerja di pedesaan; 5) Menguatkan kelembagaan kelompok; dan 6) Meningkatkan kualitas lingkungan.

Kegiatan pokok dalam PUMP Perikanan Budidaya adalah: 1) Identifikasi, seleksi dan verifikasi CL/CP; 2) Pengusulan dan penetapan pokdakan penerima BLM PUMP-PB; 3) Penyusunan dan verifikasi dokumen administrasi; 4) Proses penyaluran dan pencairan dana BLM PUMP-PB kepada Pokdakan; 5) Pendampingan, pembinaan dan pengendalian; dan 6) Pemantauan, evaluasi dan pelaporan.

\section{Pengembangan Usaha Mina Pedesaan Pengolahan dan Pemasaran Hasil Perikanan (PUMP-P2HP)}

PUMP-P2HP merupakan kegiatan pemberdayaan dimana salah satu tugasnya memfasilitasi bantuan pengembangan usaha bagi masyarakat pengolah dan pemasar hasil perikanan dalam wadah Kelompok Pengolah dan Pemasar (POKLAHSAR). POKLAHSAR merupakan kelompok usaha kelautan dan perikanan bidang pengolahan dan pemasaran sebagai pelaksana PUMP-P2HP dalam penyaluran bantuan pengembangan usaha. PUMP-P2HP bertujuan untuk meningkatkan kemampuan dan mengembangkan wirausaha bidang pengolahan dan pemasaran di pedesaan.

Pola dasar PUMP-P2HP dirancang untuk meningkatkan kemampuan POKLAHSAR yang terdiri dari kelompok pengolah dan pemasar hasil perikanan untuk mengembangkan usaha produktif dalam rangka mendukung peningkatan kemampuan dan pengembangan wirausaha bidang pengolahan dan pemasaran. Untuk pencapaian tujuan tersebut, komponen utama kegiatan PUMP-P2HP adalah: a) Keberadaan POKLAHSAR; b) Keberadaan tenaga pendamping, Tim Koordinasi, Pokja PUMP P2HP, Tim Pembina dan Tim Teknis; c) Sosialisasi dan pelatihan; d) Penyaluran dana BLM; dan e) Pemantauan, evaluasi dan pelaporan.

\section{Pemberdayaan Usaha Garam Rakyat (PUGAR)}

Pembuatan garam di Indonesia 70\% dilakukan oleh rakyat dilahan garam yang relatif sempit $(0,503 \mathrm{Ha})$ dengan teknologi pengolahan dan peralatan sederhana. Proses Pembuatan garam 
rakyat dimulai dari proses penampungan air laut/ bozeem yang berfungsi untuk tempat persediaan air laut dan mengendapkan kotoran fisik air laut, setelah itu dilakukan proses pemekatan (dengan menguapkan airnya) dan pemisahan garamnya (dengan kristalisasi). Selain usaha garam rakyat, garam diproduksi juga oleh PT garam dengan mutu yang lebih baik dibanding garam rakyat karena $\mathrm{PT}$ Garam mempunyai luas areal produksi garam yang luas.

Untuk mencapai swasembada garam nasional telah dibentuk tim swasembada garam nasional dibawah koordinasi Kementerian Koordinator Perekonomian yang beranggotakan KKP, Kementerian Perindustrian (Kemenperin) dan Kementerian Perdagangan (Kemendag). KKP bertanggungjawab pencapaian swasembada garam untuk keperluan konsumsi dengan melaksanakan intensifikasi dan revitalisasi lahan produktif, peningkatan produksi dan mutu garam rakyat, pemberdayaan petambak garam, inovasi teknologi produksidan mutu garam. Oleh KKP, pengembangan usaha garam rakyat diimplemetasikan melalui program pemberdayaan yang merupakan integrasi pemberdayaan pada masing-masing unit eselon satu dalam wadah PNPM Mandiri-KP yang disebut Program Usaha Garam Rakyat (PUGAR).

PUGAR adalah kegiatan pemberdayaan yang difokuskan pada peningkatan kesempatan kerja dan kesejahteraan bagi petambak garam dalam rangka mencapai Swasembada Garam Nasional melalui prinsip bottom-up, artinya masyarakat sendiri yang merencanakan kegiatan, melaksanakan dan melakukan monitoring dan evaluasi sesuai dengan mekanisme yang ditentukan. Melalui PUGAR, masyarakat didorong untuk melaksanakan usaha garam, sehingga target produksi untuk memenuhi kebutuhan garam konsumsi iuntuk nasional akan dapat dicapai.

\section{Pengembangan Desa Pesisir Tangguh (PDPT)}

Program PDPT dimaksudkan untuk meningkatkan kualitas lingkungan dan kesejahteraan untuk mewujudkan desa yang tangguh. Tujuannya adalah: 1) Meningkatkan pelayanan prasarana dan sarana sosial ekonomi; 2) Meningkatkan kualitas lingkungan hidup; 3) Meningkatkan kapasitas kelembagaan masyarakat dan pemerintah daerah dalam proses pengambilan keputusan secara partisipatif; dan 4) Meningkatkan kesiap-siagaan terhadap bencana dan perubahan iklim.

Pemilihan desa pesisir dilakukan dengan memenuhi sekurang-kurangnya 3 (tiga) kriteria sebagai berikut: 1) lokasi rawan bencana dan perubahan iklim; 2) mempunyai potensi ekonomi lokal unggulan; 3) masyarakat pesisir miskin namun potensial aktif dan memiliki motivasi untuk memperbaiki kehidupannya; 4) kondisi lingkungan permukiman kumuh; 5) terjadi degradasi lingkungan

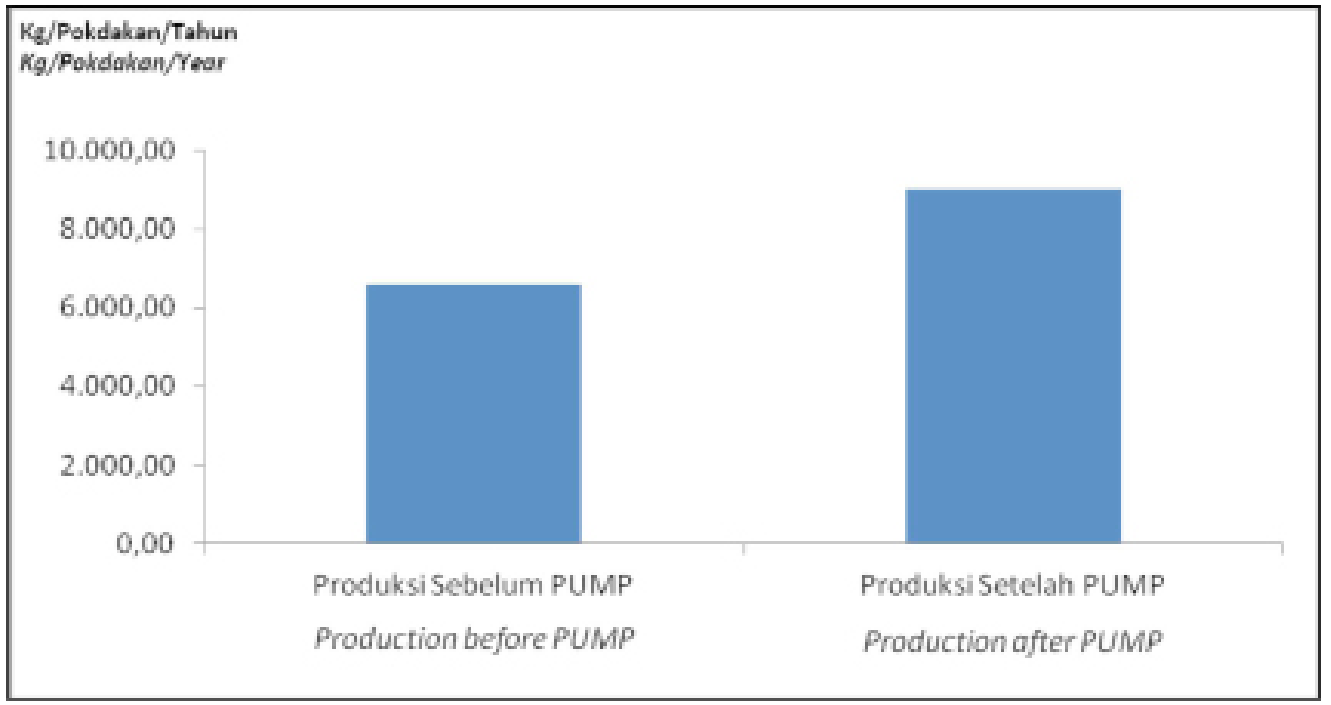

Sumber: Data diolah (2012) / Source: Processed data (2012)

Gambar 1. Produksi Perikanan Budidaya Sebelum dan Sesudah Mendapat Bantuan PUMP PB di 13 Propinsi di Indonesia, Tahun 2011.

Figure 1. Aquaculture Production Before and After PUMP Assistance Program in 13 Indonesian Provinces, 2011. 


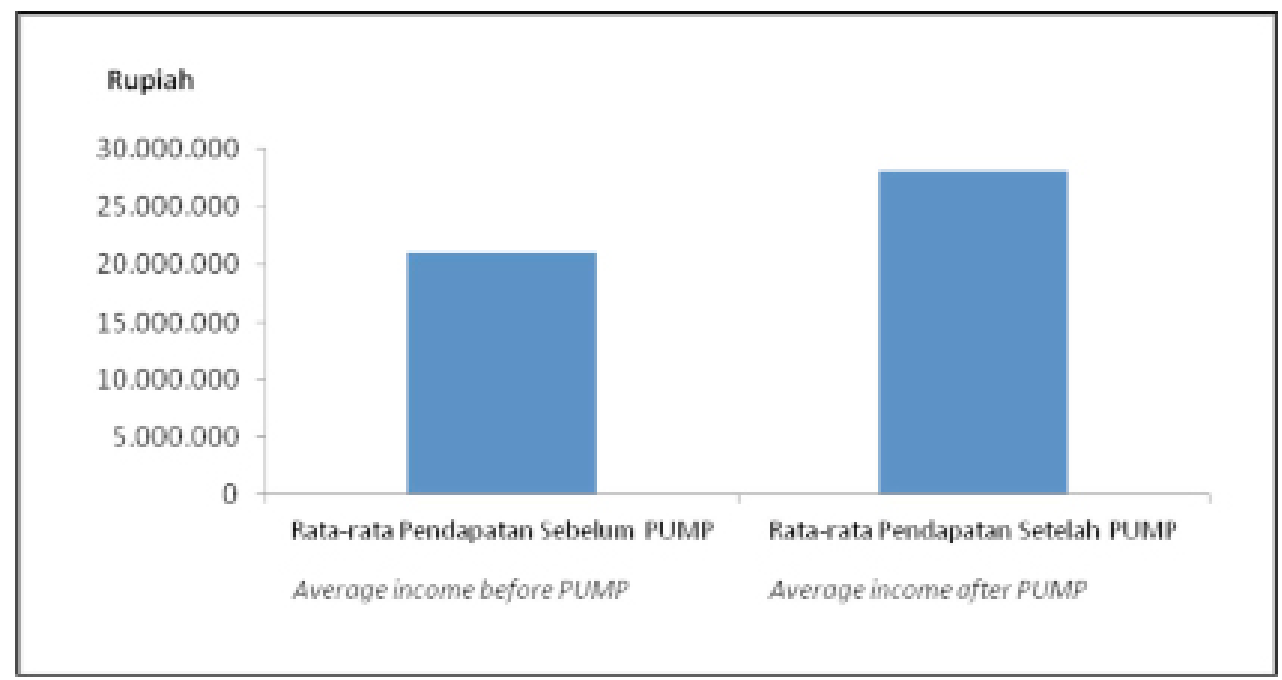

Sumber: Data diolah (2012) / Source: Processed data (2012)

Gambar 2. Rata-Rata Pendapatan Pokdakan Sebelum dan Sesudah Mendapatkan Bantuan PUMP PB di 13 Propinsi di Indonesia, Tahun 2011.

Figure 2. Average Pokdakan Income Before and After PUMP Assistance Program in 13 Indonesian Provinces, 2011.

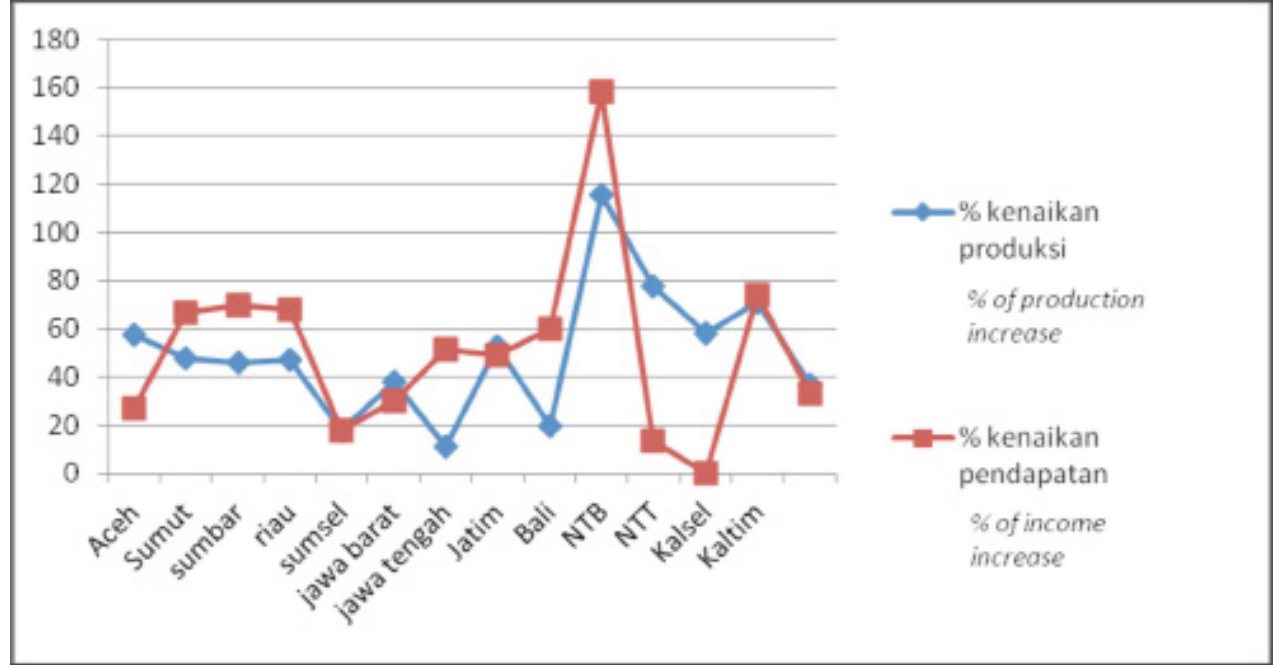

Sumber: Data diolah (2012) / Source: Processed data (2012)

Gambar 3. Sebaran Persentase Kenaikan Produksi dan Pendapatan Menurut Propinsi di Indonesia, Tahun 2011.

Figure 3. Distribution of Percentage In Production and Income Increase by Province, 2011.

pesisir; dan/atau 6) tingkat pelayanan dasar rendah. Selanjutnya desa pesisir tersebut ditetapkan dengan keputusan Bupati/Walikota.

\section{Dampak PUMP Perikanan Budidaya}

Program bantuan pemerintah pada sektor perikanan budidaya tersebar pada 33 provinsi yang diberikan kepada 2.070 Kelompok Budidaya Perikanan (Pokdakan). Secara umum bantuan diberikan dalam bentuk input produksi seperti pakan, benih dan alat-alat produksi. Berdasarkan data yang berhasil diperoleh dari 59 Pokdakan yang menerima bantuan pada 13 provinsi diketahui berdampak positif terhadap usaha yang dilakukan. Kenaikan produksi dan pendapatan pada pelaksanaan PUMP budidaya tahun 2011 disajikan pada Gambar 1 dan Gambar 2.

Berdasarkan sebaran data yang diperoleh, diketahui terjadi kenaikan yang sangat tinggi pada Propinsi NTB (Gambar 3). Komoditas yang dikembangkan oleh penerima PUMP PB di NTB 
adalah rumput laut. Kondisi sebaliknya terjadi pada Propinsi Kalimantan Selatan yang banyak mengembangkan komoditas ikan nila. Namun demikian, sulit untuk menarik kesimpulan jenis komoditas apa yang berpengaruh signifikan terhadap kenaikan produksi pada tiap-tiap propinsi (Gambar 4). belum sepenuhnya memahami jenis dan isi materi dokumen administrasi PUMP-PB sesuai dengan pedoman;

3. Penempatan PPTK sebagai tenaga pendamping PUMP-PB di daerah lokasi PUMP PB tidak merata dan tidak proporsional terhadap jumlah alokasi paket BLM PUMP-PB di kabupaten/kota tersebut;

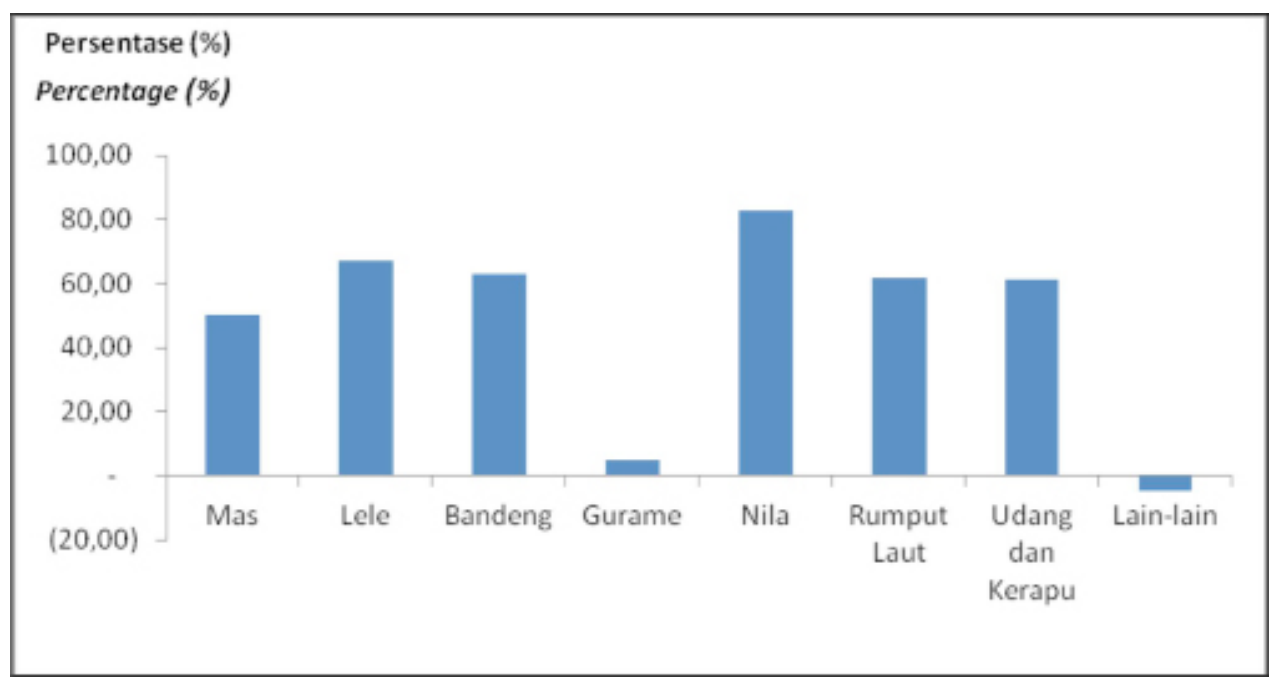

Sumber: Data diolah (2012) / Source: Processed data (2012)

Gambar 4. Peningkatan Produksi Perikanan menurut Jenis Komoditas di 13 Propinsi di Indonesia, Tahun 2011.

Figure 4. Production Increase by Type of Commodity in Provinces in Indonesia, 2011.

Beberapa permasalahan yang berhasil diidentifikasi selama pelaksanaan PUMP PB 2012 diantaranya adalah:

1. Perangkat aturan yang mendasari pelaksanaan kegiatan PUMP-PB seperti pedoman pelaksanaan (pedlak), pedoman teknis (pednis), Surat Edaran (SE) Direktur Jenderal Perbendaharaan - Kemenkeu dan alokasi paket bantuan untuk masing - masing propinsi dan kabupaten/kota mengalami keterlambatan 3 bulan karena adanya perbaikan dan penyempurnaan kebijakan. Sehingga berdampak pada proses selanjutnya dan akhirnya menyebabkan keterlambatan penyaluran BLM PUMP PB tahun 2012.

2. Tim Teknis dan Tim Pembina PUMPPB yang dibentuk oleh dinas di daerah komposisinya beragam dan sebagian
4. Kontrak PPTK berakhir Bulan November 2012 sedangkan penyaluran PUMP-PB masih dalam proses pemanfaatan bahkan beberapa diantaranya baru cair.

5. Anggaran pendukung kegiatan PUMP-PB yang dialokasikan melalui dekonsentrasi di dinas kelautan dan perikanan propinsi pada beberapa daerah direvisi untuk penghematan;

6. Beberapa kelompok yang berasal dari usulan aspirasi datanya tidak lengkap sehingga menyulitkan identifikasi;

7. Proses verifikasi dokumen oleh Tim Teknis dan Tim Pembina belum optimal;

8. Dukungan pemerintah daerah terhadap kegiatan PUMP-PB belum optimal. Sehingga dinas yang membidangi perikanan di kabupaten/kota belum 
sepenuhnya melakukan pembinaan dan pengawasan dengan baik.

\section{Dampak PUMP Perikanan Tangkap}

Pada tahun 2011 kelompok yang mendapat bantuan PUMP Perikanan Tangkap (PT) ada sebanyak 1.106 KUB yang tersebar di 33 provinsi dan $132 \mathrm{kab}$. Total nilai bantuan yang dikucurkan sebesar 110,6 milyar rupiah. Penentuan alokasi BLM per Kab/Kota didasarkan atas beberapa indikator yaitu : jumlah KUB binaan Kab/Kota, jumlah alokasi $B L M$, jumlah anggota KUB yang belum dapat BLM, kemampuan pembinaan dan pengendalian dari $\mathrm{Kab} /$ Kota dan alokasi dana pendukung.
Bantuan PUMP yang diberikan berupa : 1) Pengadaan atau perbaikan sarana penangkapan (perahu/mesin/bahan alat penangkapan ikan/alat bantu penangkapan ikan); 2) Biaya operasional (bensin/solar/minyak tanah/pelumas/es); 3) Perbengkelan nelayan; dan 4) Asuransi. Berdasarkan hasil analisis pada 149 KUB yang tersebar di 14 provinsi dan 20 kabupaten berdasarkan data dari BPSDM-KP (2011), terjadi kenaikan produksi perikanan dan peningkatan pendapatan pada kelompok sasaran dibandingkan sebelum mendapatkan bantuan PUMP PT (Gambar 5 dan Gambar 6).

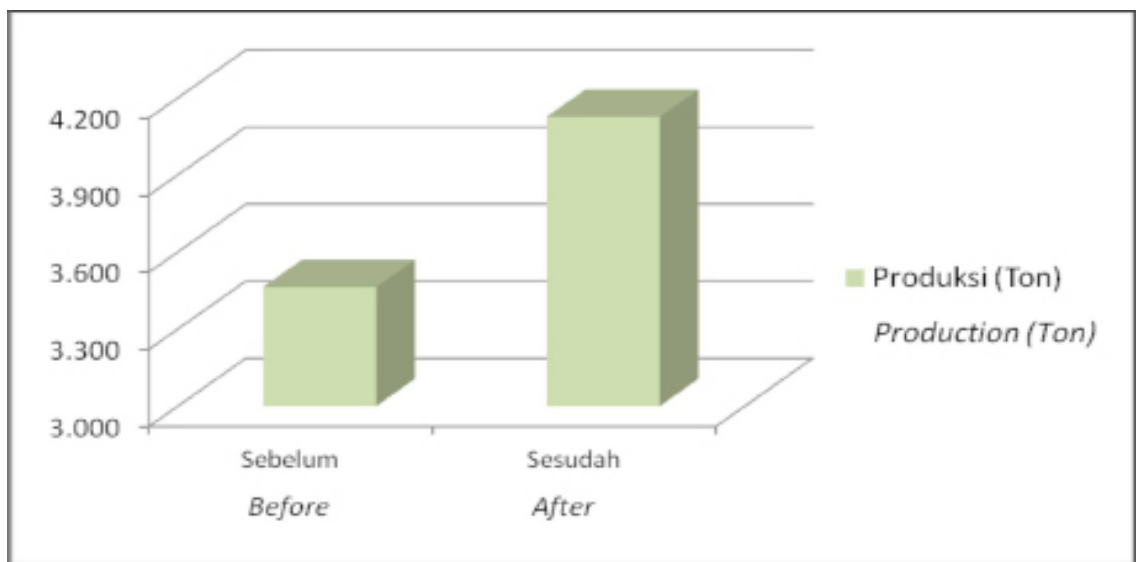

Sumber : BPSDM, KKP (2011) / Source: BPSDM, KKP (2011)

Gambar 5. Produksi KUB Sebelum dan Sesudah ada Bantuan PUMP Perikanan Tangkap di 14 Propinsi di Indonesia, Tahun 2011.

Figure 5. KUB Production Before and After PUMP Assistance Program in 14 Indonesian Provinces, 2011.

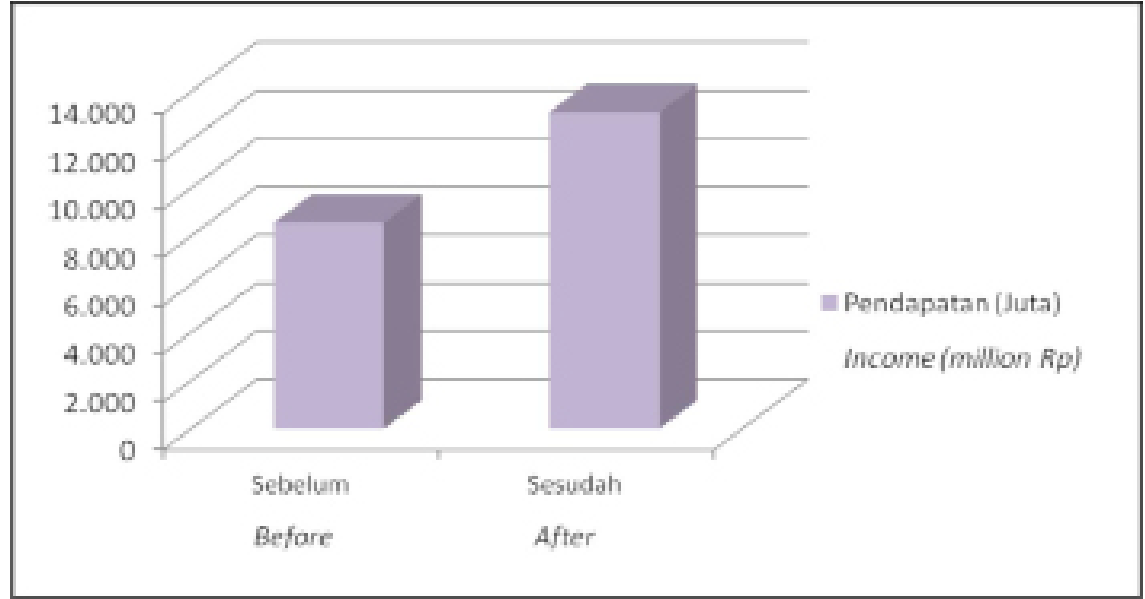

Sumber : BPSDM, KKP (2011) / Source: BPSDM, KKP (2011)

Gambar 6. Pendapatan KUB Sebelum dan Sesudah ada Bantuan PUMP Perikanan Tangkap di 14 Propinsi di Indonesia, Tahun 2011.

Figure 6. Average KUB Income Before and After PUMP Assistance Program in 14 Indonesian Provinces, 2011. 
Menurut propinsi, tingkat produksi yang dihasilkan setelah adanya bantuan paling tinggi terdapat di provinsi Jawa Timur sebesar 561 ton/ kelompok/bulan sedangkan yang paling rendah ada di provinsi Sulawesi Tenggara sebesar 2,3 ton/ kelompok/bulan (Gambar 7). Sedangkan menurut pendapatan, provinsi Kalimantan Timur merupakan provinsi yang pendapatan kelompoknya paling besar dibandingkan yang lain yakni sebesar 646.700 juta rupiah sedangkan yang paling kecil ada di provinsi Sulawesi Tenggara sebesar 31 juta rupiah (Gambar 8).

\section{Dampak PUMP Pengolahan dan Pemasaran Hasil Perikanan}

Volume penjualan sebelum ada bantuannya PUMP P2HP adalah 4,479 Kg per bulan, setelah diberikan bantuan volume penjualan meningkat menjadi $5.693 \mathrm{Kg}$ per bulan, artinya terjadi peningkatan volume produksi sebesar 27,09 persen. Volume penjualan ikan dipengaruhi oleh jenis usaha, dimana volume penjualan ikan segar lebih besar ketimbang volume untuk penjualan ikan pindang (olahan). Volume penjualan ikan segar

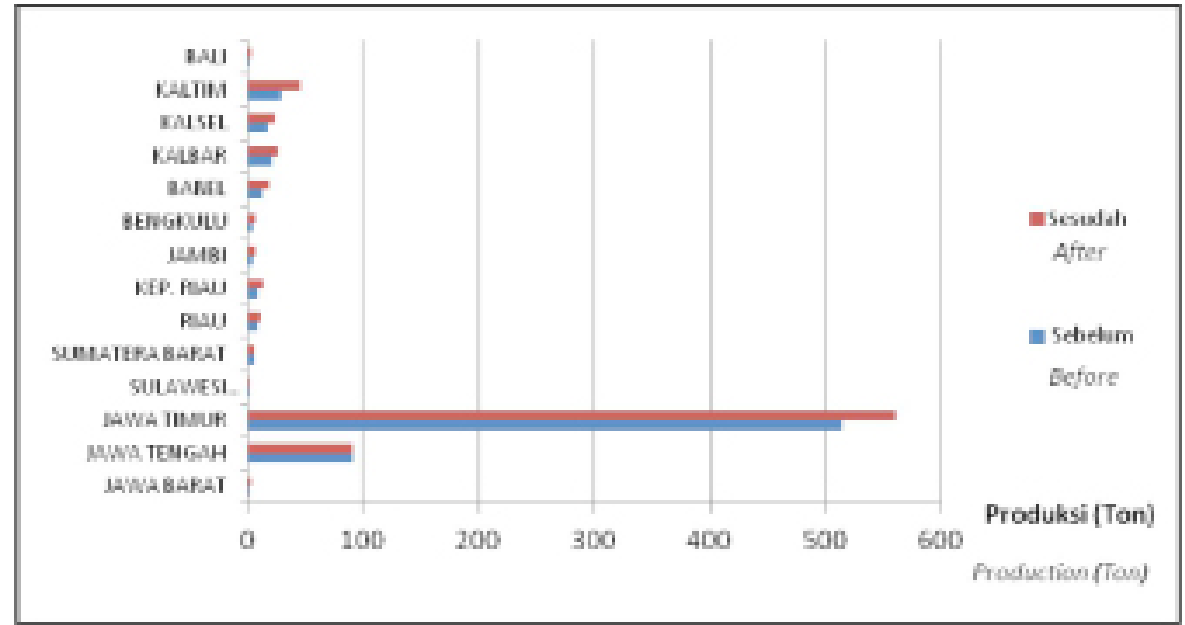

Sumber: Data diolah (2012) / Source: Processed data (2012)

Gambar 7. Produksi KUB Sebelum dan Sesudah ada Bantuan PUMP Perikanan Tangkap Menurut Provinsi di Indonesia Tahun 2011 (Ton).

Figure 7. KUB Production Before and After PUMP by Province, 2011 (Ton).

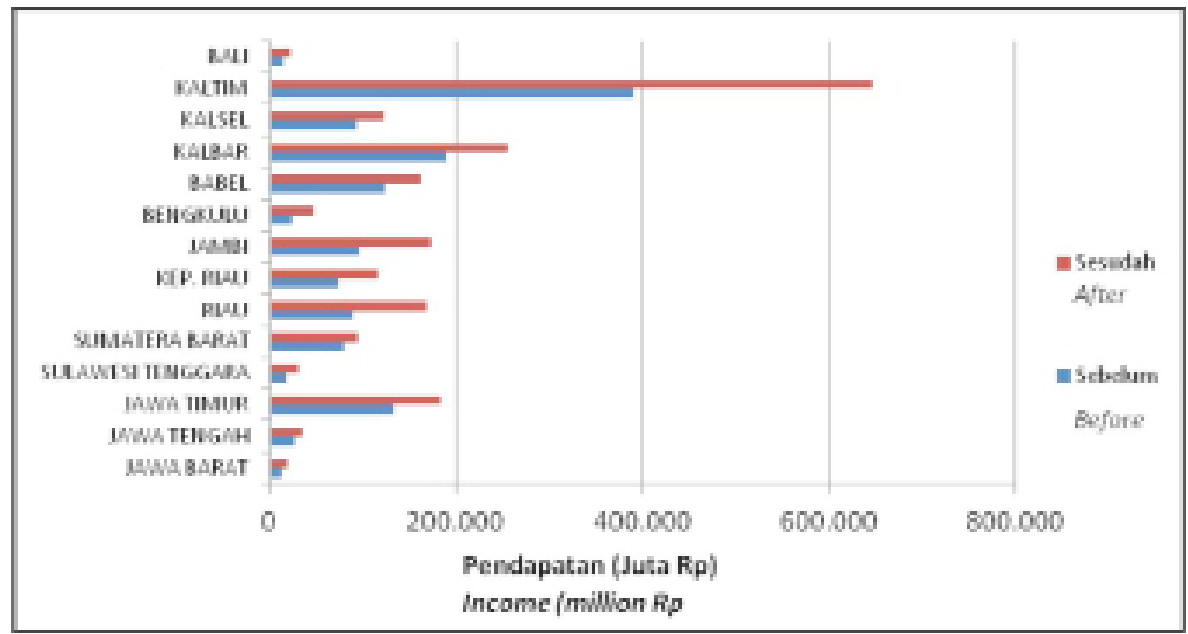

Sumber: Data diolah (2012) / Source: Processed data (2012)

Gambar 8. Pendapatan KUB Sebelum dan Sesudah ada Bantuan PUMP Perikanan Tangkap Menurut Provinsi di Indonesia Tahun 2011 (Juta Rupiah).

Figure 8. KUB Income Before and After PUMP by Province, 2011 (Million Rupiahs). 
bisa mencapai $45.000 \mathrm{Kg}$, volume penjualan ikan yang terbesar pada penjualan ikan laut. Volume penjualan ikan olahan seperti volume olahan pindah hanya mencapai $14.000 \mathrm{Kg}$.Perbandingan volume usaha pemasaran ikan olahan sebelum dan sesudah PUMP P2HP disajikan pada Gambar 9.

Peningkatan volume penjualan berdampak pada peningkatan keuntungan penerima bantuan PUMP P2HP. Sebelum ada bantuan PUMP P2HP pendapatan yang diperoleh adalah $R p 9,458,519.59$ per bulan, setelah ada bantuan PUMP pendapatan yang diterima meningkat menjadi Rp 14,885,759.67, artinya terjadi peningkatan pendapatan sebesar 57 persen. Satu hal yang perlu digaris bawahi adalah keuntungan yang diterima ini merupakan keuntungan kelompok bukan keuntungan rumah tangga, dimana 1 Poklahsar bisa mencapai $5-10$ orang per kelompok. Sama seperti halnya dengan volume penjualan, pendapatan yang diperoleh juga dipengaruhi oleh jenis usaha, dimana pendapatan dari penjualan ikan segar lebih besar dibandingkan dengan pendapatan yang diperoleh dari penjualan ikan pindang (olahan). Hal ini disebabkan oleh faktor volume penjualan dan harga, dimana volume dan harga ikan segar lebih besar ketimbang volume dan harga ikan pindang.Perbandingan pendapatan usaha pemasaran ikan sebelum dan sesudah PUMP P2HP disajikan pada Gambar 10.

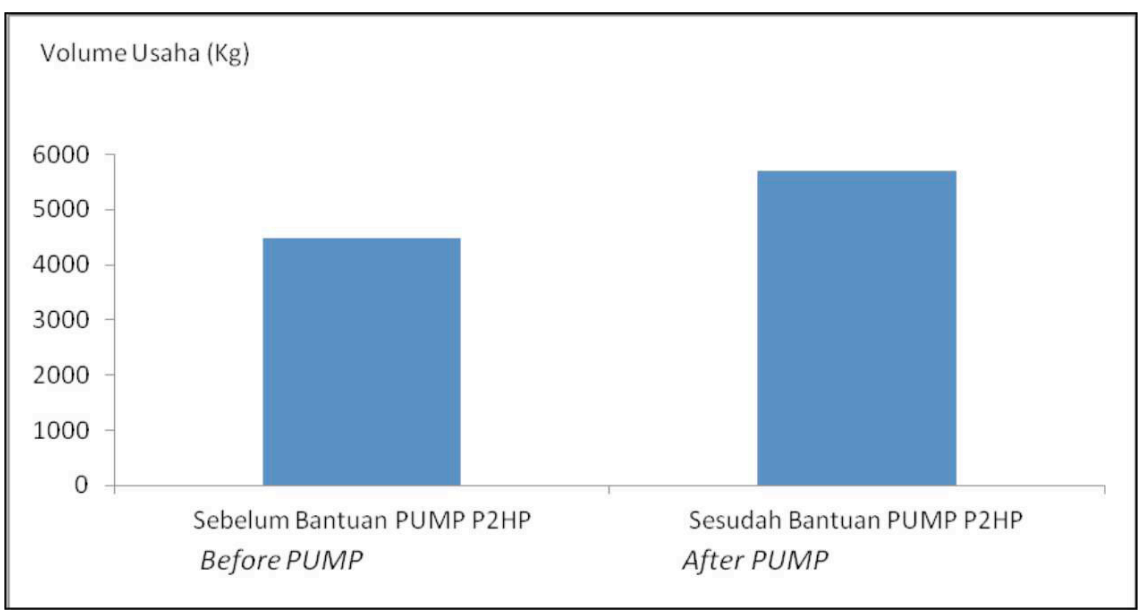

Sumber:Data diolah dari P2HP, 2011-2012 / Source: Processed P2HP Data, 2011-2012

Gambar 9. Volume Usaha Pemasaran Ikan pada Poklahsar Sebelum dan Sesudah mendapatkan PUMP P2HP, Tahun 2011.

Figure 9. Marketing Operation Volume of Fish at Poklahsars Before and After PUMP, 2011.

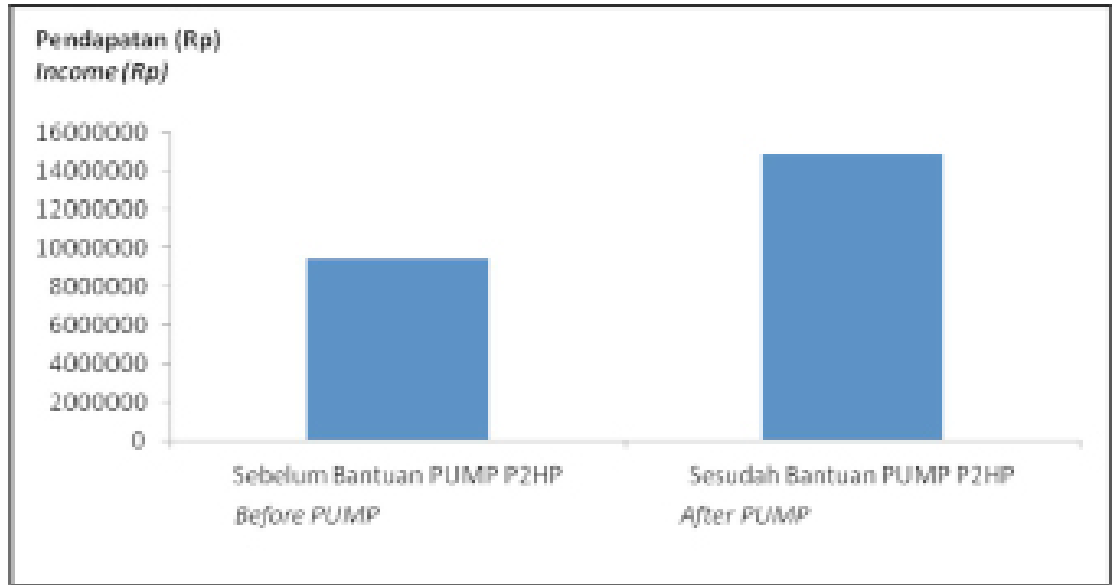

Sumber:Data diolah dari P2HP, 2011-2012 / Source: Processes P2HP Data, 2011-2012

Gambar 10. Pendapatan Usaha Pemasaran Ikan pada Poklahsar Sebelum dan Sesudah Menerima PUMP P2HPdi Indonesia, Tahun 2011.

Figure 10. Income of Fish Marketing Operations at Poklahsars Before and After PUMP, 2011. 
Pengaruh PUMP P2HP terhadap volume penjualan ikan segar, sebelum ada bantuan PUMP volume penjualan ikan segar hanya 5.737 $\mathrm{Kg}$ per bulan per kelompok sasaran. Sedangkan sesudah ada bantuan volume penjualan ikan segar meningkat menjadi hanya $7.493 \mathrm{Kg}$ per bulan per kelompok sasaran.Wilayah untuk bantuan PUMP ikan segar rata-rata berada di wilayah Timur Indonesia seperti Mamuju, Palu, Enrekang, dan Halmahera Utara.Perbandingan volume penjualan ikan segar sebelum dan sesudah PUMP P2HP disajikan pada Gambar 11.
Sebelum ada bantuan PUMP P2HP pendapatan yang diperoleh oleh pemasar ikan olahan adalah $\mathrm{Rp} 7.853 .838$ per bulan. Setelah ada bantuan PUMP pendapatan yang diterima pemasar ikan olahan meningkat menjadi Rp 11.295.230 (Gambar 12). Berarti terjadi peningkatan pendapatan sebesar 44 persen. Ikan olahan yang dijual berupa ikan pindang, ikan kering, kerupuk ikan, ikan goring, bandeng, ikan presto, ikan asap, ikan asap, dan ikan panggang.

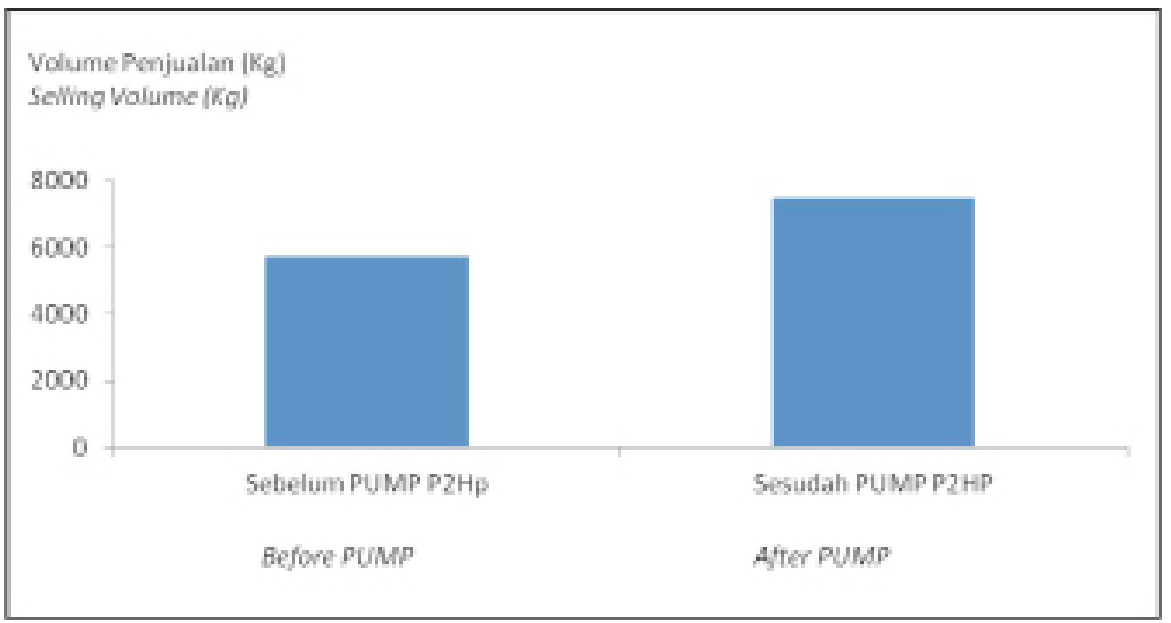

Sumber: Data diolah dari P2HP, 2011-2012 / Source: Processes P2HP Data, 2011-2012

Gambar 11. Volume Penjualan Ikan Segar pada Poklahsar Sebelum dan Sesudah Menerima PUMP P2HPdi Indonesia, Tahun 2011.

Figure 11. Fresh Fish Selling Volume at Poklahsars Before and Aftr PUMP, 2011.

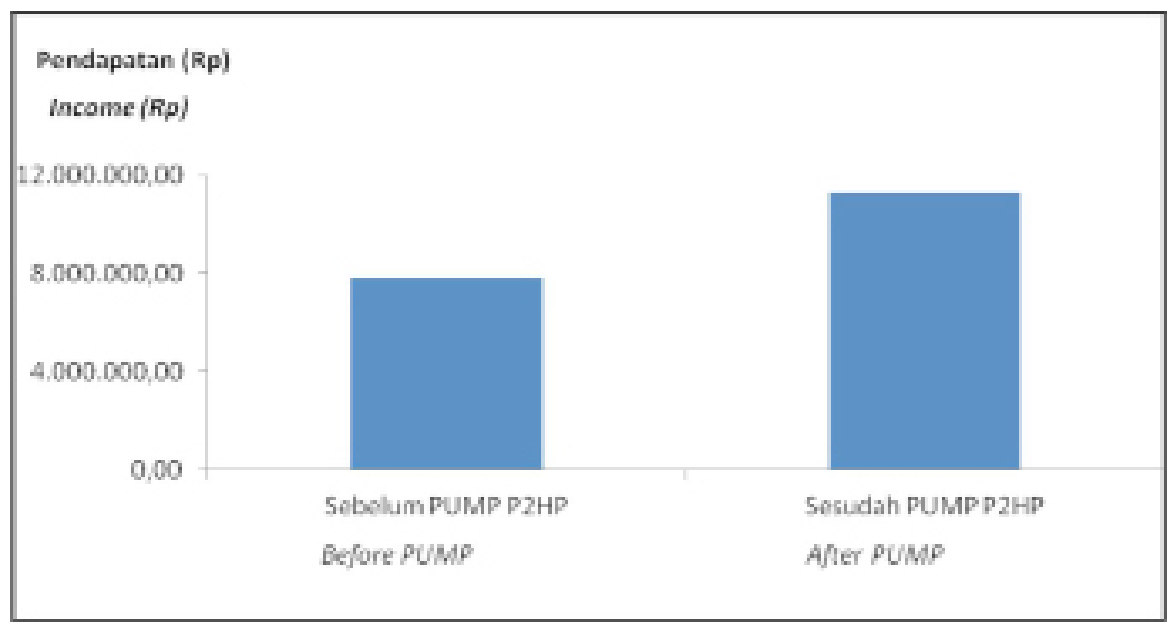

Sumber:Data diolah dari P2HP, 2011-2012 / Source: Processed P2HP data, 2011-2012

Gambar 12. Perbandingan Pendapatan Penjual Ikan Olahan Sebelum dan Sesudah Bantuan PUMP P2HPdi Indonesia, Tahun 2011.

Figure 12. Comparison of Seller Income Before and After PUMP, 2011. 
Volume produksi ikan olahan sebelum ada bantuannya PUMP P2HP adalah $1.501 \mathrm{Kg}$ per bulan, setelah diberikan bantuan volume ikan olahan meningkat menjadi $1.722 \mathrm{Kg}$ per bulan, artinya terjadi peningkatan volume produksi sebesar 14,69 persen (Gambar 13). Pengolahan ikan yang dikelola oleh Poklasar meliputi pengolahan rumput laut, bakso, abon, kerupuk ikan, bandeng, otak-otak, pindang, ikan asin, dan ikan goreng.

\section{Dampak PUGAR}

Kementerian Kelautan dan Perikanan (KKP) pada tanggal 26 Desember 2009 mencanangkan Swasembada Garam Nasional. Strategi pencapaian swasembada garam dilakukan melalui Program Pemberdayaan Usaha Garam Rakyat (PUGAR) dalam rangka peningkatan produksi dan kualitas garam rakyat serta kesejahteraan garam rakyat melalui prinsip pemberdayaan masyarakat yang dilaksanakan melalui prinsip bottom-up. Sebagai dasar pelaksanaanan Progam PUGAR ditetapkanlah Peraturan Menteri Kelautan dan Perikanan Nomor: PER.06/MEN/2011 tentang pemberdayaan masyarakat pegaraman melalui Pemberdayaan Usaha Garam Rakyat (PUGAR). PUGAR merupakan upaya kegiatan pemberdayaan melalui fasilitasi bantuan pengembangan usaha bagi petambak rakyat dalam wadah Kelompok Usaha Kelautan dan Perikanan.

Rata-rata produksi secara nasional penerima bantuan PUGAR sebesar 50.502,74 ton, sementara rata-rata produksi bantuan Non PUGAR sebesar $11.340,16$ ton. Dalam hal ini, terlihat dengan pemberian bantuan PUGAR terdapat perbedaan produksi lebih besar dibandingkan dengan non PUGAR. Produksi terbesar disumbangkan oleh wilayah Jawa dan P. Madura 98.471,51 ton. Produksi terbesar ke 2 adalah wilayah Sulawesi menyumbang 9.705,7 ton, disusul wilayah Bali dan Nusa Tenggara berproduksi $7.221,59$ ton dan wilayah Sumatera memberikan kontribusi sebanyak 1.002,25 Kg. Sedangkan produksi garam non PUGAR pada wilayah Sumatera sebesar 808,40 Ton, wilayah Jawa dan P. Madura 98.471,51 ton; wilayah Bali dan Nusa Tenggara $9.360,36$ ton serta wilayah Sulawesi 9.705,66 ton. Produksi garam PUGAR dan Non Pugar disajikan pada Gambar 14.

Garam PUGAR mempunyai produktivitas lebih tinggi dibandingkan dengan produktivitas garam non PUGAR. Produktivitas garam PUGAR mencapai 97 ton/ha dan non PUGAR sebesar 74 ton/ha. Perbandingan produktivitas garam PUGAR dan non PUGAR dapat dilihat pada Gambar 15.

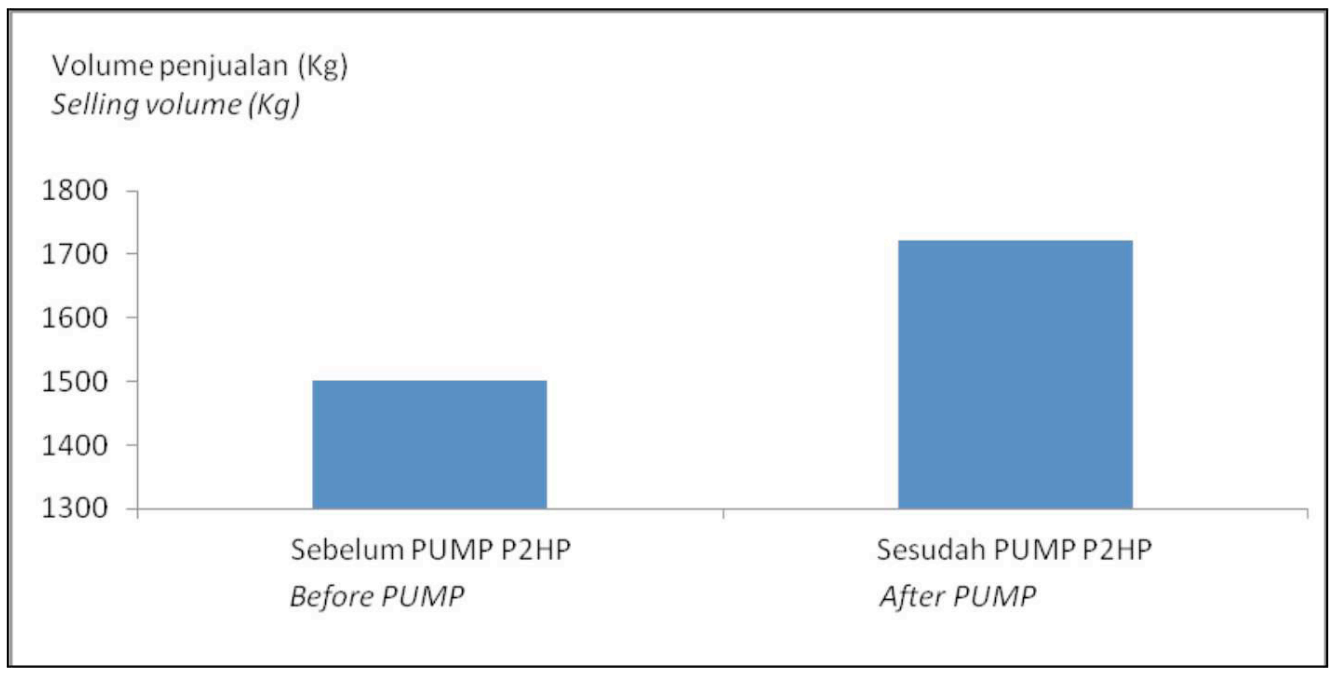

Sumber:Data diolah dari P2HP, 2011-2012 / Source: Processed P2HP data, 2011-2012

Gambar 13. Perbandingan Volume Penjualan Ikan Olahan Sebelum dan Sesudah Bantuan PUMP P2HPdi Indonesia, Tahun 2011.

Figure 13. Comparison of Selling Volume of Poklahsars Before and After PUMP, 2011. 


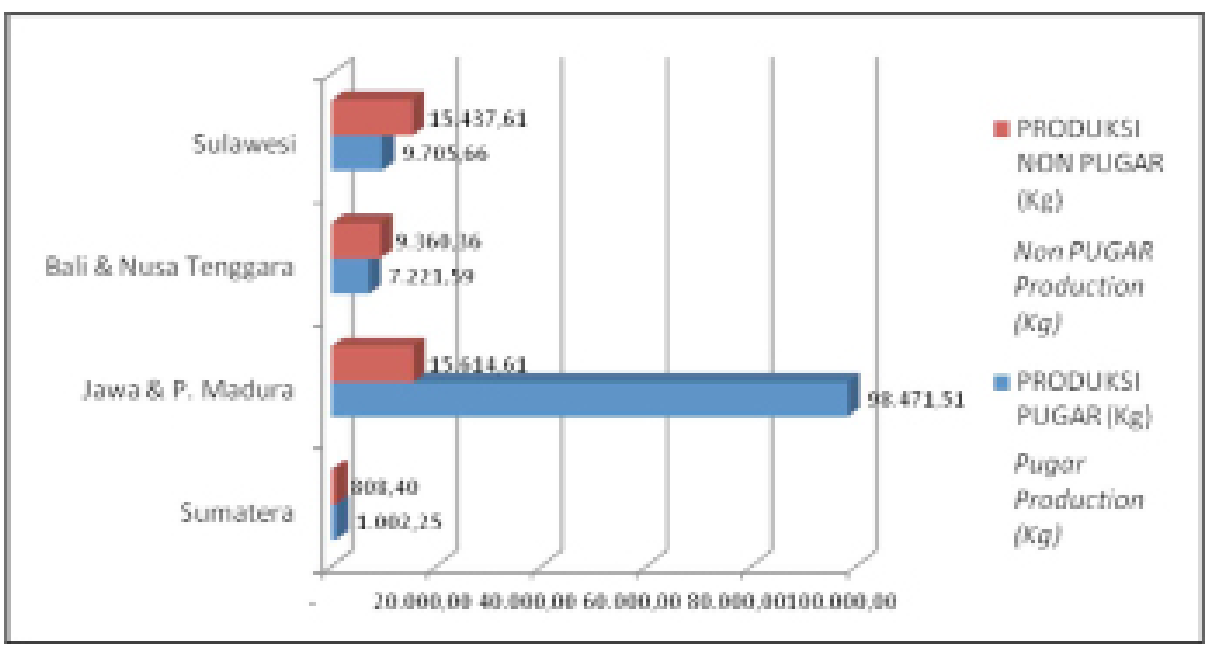

Sumber: Data Ditjen KP3K Diolah, 2013 / Source: Processed KP3K data, 2013

Gambar 14. Produksi Garam PUGAR dan Non PUGAR Menurut Wilayah di Indonesia, Tahun 2012. Figure 14. Salt Production of PUGAR and Non PUGAR Salt Pond Operators by Regions, 2012.

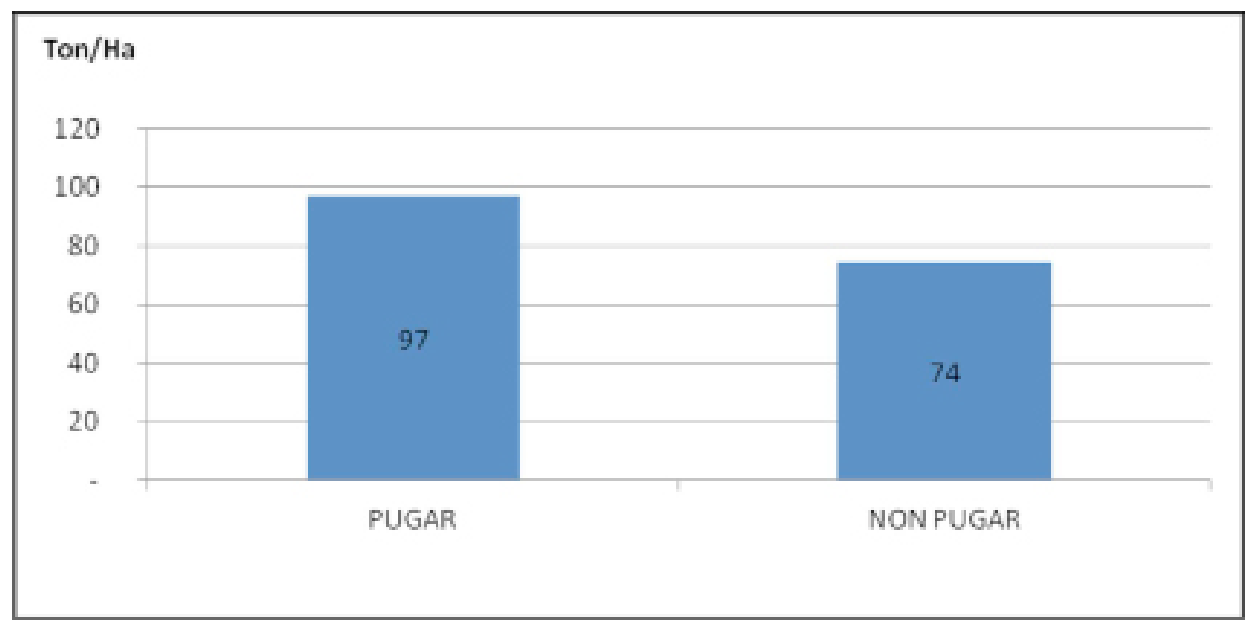

Sumber: Data Ditjend KP3K Diolah, 2013 / Source: Processed KP3K data, 2013.

Gambar 15. Produkvitas Garam PUGAR dan Non PUGAR di Indonesia, Tahun 2012 (Ton/Ha). Figure 15. Productivity of PUGAR and Non PUGAR Salt Pond Operators, 2012.

Salah satu faktor yang dapat dijadikan kekuatan dalam melakukan usaha garam adalah belum ada substitusi produk garam yang selalu dibutuhkan. Dengan adanya kebutuhan ini, petambak seharusnya memiliki kekuatan besar untuk mempengaruhi pasar garam, namun karena dihadapkan dengan berbagai kendala dalam melakukan usaha garam rakyat yang masih tradisonal, kemudian mengandalkan cuacadan kurangnya sarana dan prasarana usaha, petambak hanya dapat menghasilkan garam bermutu rendah dalam waktu yang terbatas. Kebijakan pemerintah yang meliputi kebijakan produksi melalui PUGAR, penetapan harga dasar garam dan larangan impor garam merupakan peluang terbesaryang dimiliki petambak garam yang dapat dimanfaatkan untuk mengatasi ancaman usaha garam.

\section{Dampak PDPT}

Prioritas pelaksanaan kegiatan PDPT pada tahun 2012, terdiri dari bina lingkungan/ infrastruktur, bina siaga bencana, bina sumberdaya manusia, bina usaha, dan bina manusia. Kegiatan Bina Siaga Bencana dan Perubahan Iklim berupa penyediaan prasarana dan sarana siaga bencana dan perubahan iklim, pembangunan struktur/sarana untuk mitigasi bencana seperti: Seawall, tanggul penahan gelombang, APO (alat pemecah ombak), Jalur evakuasi, papan informasi dan ramburambunya, Sistem Informasi (radio komunitas), dan lain-lain. 
Selanjutnya kegiatan Bina Sumber Daya berupa peningkatan dan/atau perbaikan ekosistem pesisir seperti: 1) Perlindungan dan konservasi untuk ekosistem pesisir (mangrove, lamun dan terumbu karang); 2) Rehabilitasi ekosistem pesisir (mangrove, lamun dan terumbu karang) : penanaman mangrove, penanaman cemara laut, penghijauan sempadan pantai dan sungai, transplantasi karang; 3) Pencegahan dan penanganan pencemaran lingkungan pesisir; 4) Pengembangan pemanfaatan sumberdaya yang mengutamakan aspek keberlanjutan (silvofisheries, restocking, dan lain-lain); dan Pengelolaan dan pengawasan sumber daya pesisir.

Kegiatan Bina Lingkungan dan Infrastruktur berupa embangunan dan/atau perbaikan lingkungan atau infrastruktur meliputi penyediaan/ perbaikan sarana dan prasarana dasar: air bersih, listrik dan penerangan, jalan dan jembatan, fasilitas tambat kapal, drainase, sanitasi dan MCK, sampah, fasilitas umum dan fasilitas sosial lainnya.

Kegiatan Bina Usaha berupa penyediaan sarana kegiatan usaha seperti:bantuan sarana penunjang usaha perikanan tangkap, perikanan budidaya serta pengolahan dan pemasaran hasil perikanan; bantuan sarana mata pencaharian alternatif, (seperti: perahu wisata, pondok wisata, alat selam untuk wisata bawah laut, alat produksi kerajinan hasil laut, dan daur ulang limbah, dan lain-lain); kegiatan usaha pendukung industrialisasi kelautan skala kecil (seperti bantuan sarana pengembangan bioteknologi skala kecil); dan bantuan modal usaha.

Kegiatan Bina Sumber Daya Manusia meliputi: 1) Pelatihan dan pendampingan teknologi budidaya perikanan, perikanan tangkap, dan pengolahan hasil perikanan; 2) Penyuluhan dan Pelatihan konservasi, rehabilitasi, dan pengelolaan sumber daya pesisir; dan 3) Sosialisasi dan pelatihan mitigasi bencana.

Kegiatan Bina Kelembagaan meliputi: 1) Pelatihan peningkatan kapasitas kelembagaan aparatur dan masyarakat desa; 2) Pembentukan kelompok nelayan/petani; dan 3) Pembentukan koperasi dan lembaga bantuan keuangan.

Pada tahun 2012, kelompok penerima bantuan (KMP) sebanyak 535 kelompok yang tersebar di 16 Kabupaten/Kota pesisir. Jumlah anggota KMP sebanyak 4.435 orang dengan jumlah tenaga pendamping sebanyak 64 orang (Tabel 1).

Tabel 1. Pelaksanaan Kegiatan PDPT Tahun 2012.

Table 1. Implemented PDPT Activities, Year 2012.

\begin{tabular}{|c|c|c|c|c|c|c|c|}
\hline No & $\begin{array}{l}\text { Kabupaten } \\
\text { (Regency) }\end{array}$ & $\begin{array}{l}\text { Jumlah } \\
\text { KMPI } \\
\text { Number } \\
\text { of KMP }\end{array}$ & $\begin{array}{l}\text { Jumlah Anggota } \\
\text { KMP (orang) } \\
\text { Number of } \\
\text { KMP member } \\
\text { (person) }\end{array}$ & $\begin{array}{c}\text { Jumlah Tenaga } \\
\text { Pendamping (orang) } \\
\text { Number of } \\
\text { Extension Worker } \\
\text { (person) }\end{array}$ & $\begin{array}{c}\text { Jumlah } \\
\text { Tenagal } \\
\text { Motivator } \\
\text { Number of } \\
\text { motivator }\end{array}$ & $\begin{array}{c}\text { Jumlah } \\
\text { Kegiatan yang } \\
\text { Dilaksanaka } \\
\text { Number of } \\
\text { implemented } \\
\text { Activities }\end{array}$ & Total \\
\hline 1 & Asahan & 26 & 260 & 4 & 9 & 27 & 326 \\
\hline 2 & Pesisir Selatan & 30 & 300 & 4 & 9 & 30 & 373 \\
\hline 3 & Kaur & 30 & 248 & 4 & 9 & 31 & 322 \\
\hline 4 & Tangerang & 30 & 227 & 4 & 9 & 33 & 303 \\
\hline 5 & Sukabumi & 38 & 183 & 4 & 9 & 54 & 288 \\
\hline 6 & Kendal & 30 & 261 & 4 & 9 & 33 & 337 \\
\hline 7 & Kulon Progo & 34 & 328 & 4 & 9 & 34 & 409 \\
\hline 8 & Pacitan & 30 & 310 & 4 & 9 & 28 & 381 \\
\hline 9 & Pontianak & 31 & 300 & 4 & 9 & 30 & 374 \\
\hline 10 & $\begin{array}{l}\text { Kotawaringin } \\
\text { Barat }\end{array}$ & 33 & 261 & 4 & 9 & 30 & 337 \\
\hline 11 & Banjar & 30 & 227 & 4 & 9 & 32 & 302 \\
\hline 12 & Parigi Moutong & 30 & 300 & 4 & 9 & 31 & 374 \\
\hline 13 & Pinrang & 30 & 300 & 4 & 9 & 31 & 374 \\
\hline 14 & Kota Bau-Bau & 30 & 338 & 4 & 9 & 48 & 429 \\
\hline & Seram Bagian & & & & & & \\
\hline 15 & Barat & 30 & 300 & 4 & 9 & 30 & 373 \\
\hline \multirow[t]{2}{*}{16} & Teluk Wondama & 30 & 292 & 4 & 9 & 30 & 365 \\
\hline & Jumlah & 492 & 4435 & 64 & 144 & 532 & 5667 \\
\hline
\end{tabular}

Sumber:KP3K, 2012 / Source: KP3K, 2012 


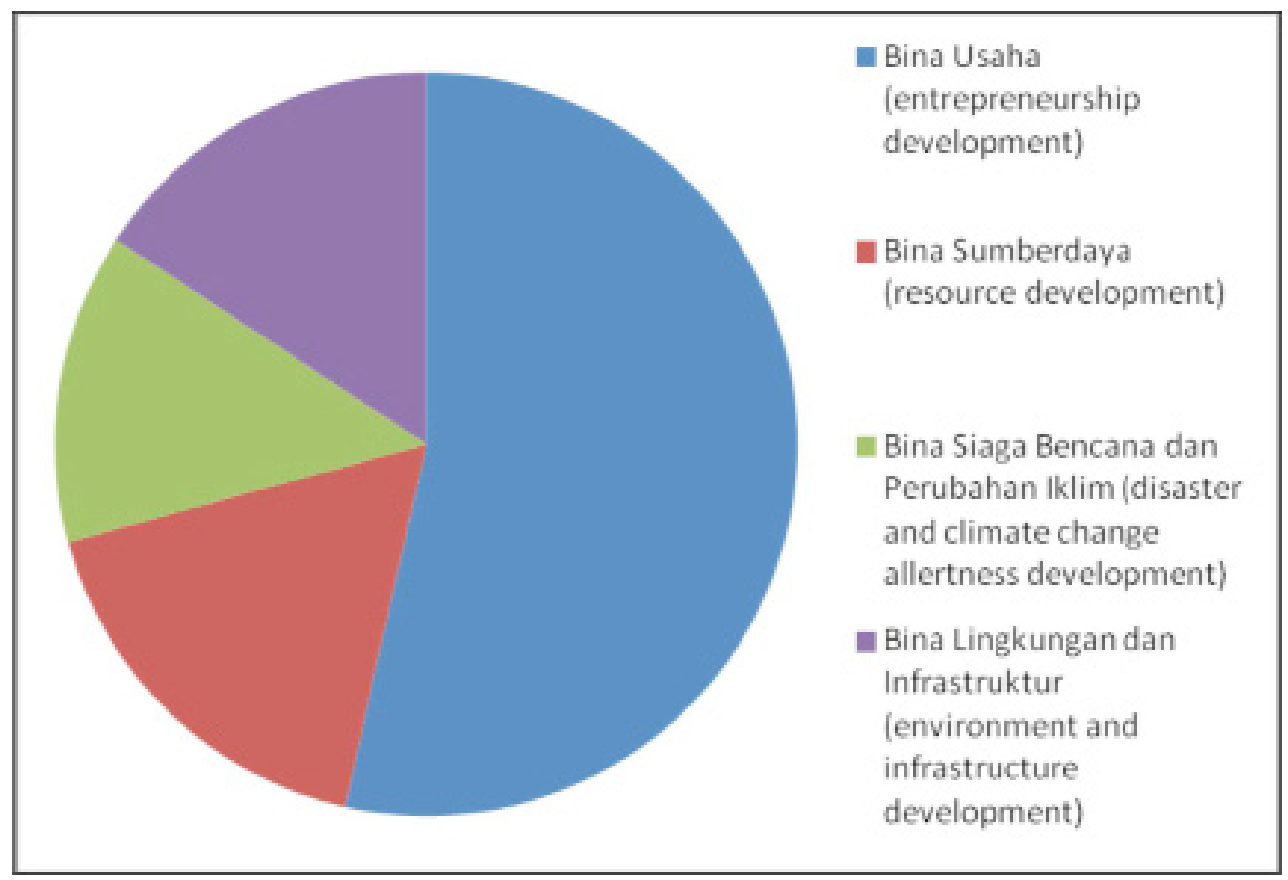

Sumber:KP3K, 2012 / Source: KP3K, 2012

\section{Gambar 16. Kegiatan PDPT Berdasarkan Penyaluran BLM Tahun 2012. Figure 16. BLM Distributionof Different PDPT Activities, 2012.}

Hal ini membuktikan ketidakseimbangan antara jumlah orang dan kelompok yang dibina dengan jumlah pendamping. Artinya, satu orang mendampingi 8 kelompok sasaran atau satu orang mendampingi 69 orang, jauh di atas keidealan, dimana idealnya satu orang mendampingi $20-25$ orang. Pemerintah dalam hal ini KKPdiharapkan memperhatikan kebijakan ini untuk mengatasi solusi ketidakseimbangan tenaga pendamping dan jumlah binaan (Gambar 16).

\section{PENUTUP}

Dengan memanfaatkan ketersediaan data yang terdapat pada Ditjen-Ditjen pelaksana PUMP, PUGAR dan PDPT, Balai Besar Penelitian Sosial Ekonomi Kelautan dan Perikanan (BBPSEKP) telah melakukan kajian evaluasi dampak PNPM Mandiri KP. Secara umum, dari data yang tersedia tersebut dapat disimpulkan bahwa bantuan PNPM Mandiri KP memberikan dampak positif terhadap para penerimanya. Namun demikian, kajian lebih mendalam perlu dilakukan dengan melakukan survey yang terprogram.

Kinerja outcome PNPM Mandiri KP pada kelompok perikanan tangkap, pembudidaya ikan, pengolah/pemasar, dan petambak garam berturutturut adalah:
- peningkatan produksi dan produktivitas sebesar 19 persen, 37 persen, $27 \%$ dan 31 persen.

- peningkatan pendapatan sebesar 54 persen, 33 persen, 57 persen dan 31 persen.

Kinerja manfaat dan dampak seperti tercantum dalam Petunjuk Pelaksanaan (perkembangan usaha, berfungsinya kelompok sebagai lembaga ekonomi dan berkurangnya kemiskinan di lokasi program) tidak dapat dilaporkan karena sistem pendataan di Ditjen-Ditjen pelaksana PUMP tidak mencakup pengukuran kinerja tersebut.

Untuk melaksanakan pengkajian dampak PUMP/PUGAR/PDPT padawaktu-waktu berikutnya, BBPSEKP telah mempersiapkan hal-hal sebagai berikut: 1) Kerangka penyempurnaan pendataan untuk masing-masing ditjen pelaksana PUMP/ PUGAR/PDPT; dan 2) Kerjasama dengan Pusat Penyuluhan BPSDMKP, dengan maksud untuk mengoptimalkan keberadaan penyuluh untuk melakukan enumerasi berdasarkan kerangka kajian yang disiapkan oleh BBPSE KP.

Rekomendasi yang diusulkan sebagai perbaikan kebijakan di masa mendatang diantaranya adalah: 1) program harus diarahkan 
pada pembinaan dalam aspek kewirausahaan, manajemen usaha dan manajemen keuangan; 2) masyarakat yang tidak menerima bantuan dilibatkan sebagai bagian dari skenario program; dan 3) menyertakan program-program pembinaan dan pendampingan yang diarahkan pada penyiapan penerima program untuk memanfaatkan kenaikan pendapatannya untuk digunakan sebagai fasilitas yang dapat meningkatkan produksi dan pendapatan lebih besar lagi pada saat mereka tidak lagi mendapatkan bantuan.

\section{DAFTAR PUSTAKA}

Arikunto, S. 1998. Prosedur Penelitian : Suatu Pendekatan Praktek. Jakarta: Rineka Cipta.

Badan Pusat Statistik. 2008. Profil Kemiskinan di Indonesia Maret 2008. Berita Resmi Statistik No. 37/07/Th. XI 1 Juli 2008. BPS. Jakarta.

Badan Pengembangan Sumberdaya Manusia Kelautan dan Perikanan. 2011. Evaluasi Hasil Pendampingan Penyuluh Perikanan Tenaga Kontrak (PPTK) terhadap Program PUMP Perikanan Tangkap, Perikanan Budidaya, dan P2HP Tahun 2011. BPSDM KP. Jakarta.

DJPB. 2012. Evaluasi Pelaksanaan Kegiatan Pengembangan Usaha Mina Pedesaan Perikanan Budidaya(PUMP_PB) Tahun 2011 dan Tahun 2012. Jakarta : Direktorat Usaha Direktorat Jenderal Perikanan Budidaya KKP.

DJPB. 2012. Pedoman TeknisKegiatan Pengembangan UsahaMina Pedesaan Perikanan Budidaya(PUMP-PB) Tahun 2012. Jakarta: Direktorat Jenderal Perikanan Budidaya KKP.

DJPT. 2012. Evaluasi Pengembangan Usaha Mina Perdesaan (PUMP) Perikanan Tangkap. Jakarta: Direktorat Jenderal Perikanan Tangkap KKP.
DJPT. 2012. Pedoman TeknisPengembangan Usaha Mina Perdesaan (PUMP)Perikanan TangkapDalam Rangka PelaksanaanProgram Nasional Pemberdayaan Masyarakat (PNPM)Mandiri - Kelautan Dan Perikanan. Jakarta: Direktorat Jenderal Perikanan Tangkap KKP.

Kementerian Kelautan dan Perikanan. 2012. Pelaksanaan Program Nasional Pemberdayaan Masyarakat Mandiri Kelautan Dan Perikanan Tahun 2011 dan 2012. Bahan Paparan Sekretaris Jendral KKP dalam Acara Evaluasi PNPM Mandiri KP Tahun 2012 di Jakarta pada Tanggal 10 Desember 2012. KKP. Jakarta.

KP3K. 2013. Perkembangan Kegiatan Pengembangan Desa Pesisir Tangguh (PDPT) 2012. Jakarta: Direktorat Pesisir dan Lautan Direktorat Jenderal Kelautan Pesisir dan Pulau-Pulau Kecil KKP.

KP3K. 2012. Pelaksanaan PUGAR 2012. Jakarta Direktorat Pemberdayaan Masyarakat Pesisir Dan Pengembangan Usaha, Direktorat Jenderal Kelautan Pesisir dan Pulau-Pulau Kecil KKP

P2HP. 2012. Keputusan Direktur Jenderal Pengolahan dan Pemasaran Hasil Perikanan Nomor KEP.312/DJ-P2HP/2012 tentang Pedoman Teknis Pengembangan Usaha Mina Pedesaan Pengolahan dan Pemasaran Hasil Perikanan Tahun 2012. Jakarta: Direktur Jenderal Pengolahan dan Pemasaran Hasil Perikanan KKP.

Sugiyono. 2008. Metode Penelitian Kuantitatif Kualitatif dan R\&D (edisi pertama). Bandung: Alfabeta.

Suhaimi, U. 1999. Focus Group Discussion Panduan Bagi Peneliti Studi Kualitatif-Studi Dampak Sosial Krisis Moneter. Jakarta: Badan Pusat Statistik dan Asian Development Bank.

The World Bank. 2004. Mewujudkan Pelayanan Umum Bagi Masyarakat Miskin. Laporan Pembangunan Dunia 2004. World Bank. Washington DC. 